\title{
17-KETOSTEROID EXCRETION IN TWO UNUSUAL FORMS OF RHEUMATOID DISEASE
}

\author{
BY
}

\author{
M. H. POND
}

From the Department of Chemical Pathology, King's College Hospital, London

(RECEIVED FOR PUBLICATION NOVEMBER 19, 1953)

Davison, Koets, and Kuzell $(1947,1949)$ found an abnormally high average urinary excretion of 17-ketosteroids in thirteen male patients with ankylosing spondylitis. In some cases, radiotherapy restored the excretion to normal. These results appeared worthy of further investigation. The urinary 17-ketosteroid excretion of a number of patients with ankylosing spondylitis and Sjögren's syndrome, in which rheumatoid manifestations are a common feature, has therefore been measured.

\section{Experiments}

Total neutral 17-ketosteroid estimations were carried out on 24-hr urine samples of eleven female patients with Sjögren's disease, and one female and five male patients with ankylosing spondylitis, all before treatment, or during an exacerbation of the disease. The method of analysis was similar to that recommended by the M.R.C. committee for clinical endocrinology. In three patients with Sjögren's syndrome and five with ankylosing spondylitis, the quantitative composition of the 17-ketosteroids was determined by separation into eight main fractions by adsorption chromatography (Pond, 1951).

\section{Results}

The results of the total 17-ketosteroid assays are shown in Table I. The detailed results of the fractionation of the 17-ketosteroid extracts have been
TABLE I

TOTAL NEUTRAL 17-KETOSTEROID VALUES (mg./24 hrs excreted, corrected nearest whole number)

\begin{tabular}{|c|c|c|c|c|}
\hline $\begin{array}{c}\text { Type of } \\
\text { Rheumatic } \\
\text { Disease }\end{array}$ & $\begin{array}{l}\text { Case } \\
\text { No. }\end{array}$ & Sex & $\begin{array}{c}\text { Age } \\
\text { (yrs) }\end{array}$ & $\begin{array}{l}\text { Total 17- } \\
\text { ketosteroids } \\
\text { (mg.) }\end{array}$ \\
\hline \multirow[t]{2}{*}{$\begin{array}{l}\text { Sjögren's } \\
\text { Syndrome }\end{array}$} & $\begin{array}{r}1 \\
2 \\
3 \\
4 \\
5 \\
6 \\
7 \\
8 \\
9 \\
10 \\
11\end{array}$ & $\begin{array}{l}\mathbf{F} \\
\mathbf{F} \\
\mathbf{F} \\
\mathbf{F} \\
\mathbf{F} \\
\mathbf{F} \\
\mathbf{F} \\
\mathbf{F} \\
\mathbf{F} \\
\mathbf{F} \\
\mathbf{F}\end{array}$ & $\begin{array}{l}54 \\
47 \\
36 \\
54 \\
71 \\
51 \\
52 \\
53 \\
64 \\
49 \\
62\end{array}$ & $\begin{array}{l}2 \\
2 \\
3 \\
3 \\
3 \\
2 \\
3 \\
3 \\
1 \\
2 \\
2\end{array}$ \\
\hline & $\begin{array}{c}11 \\
\text { total }\end{array}$ & $\mathbf{F}$ & $\begin{array}{c}54 \\
\text { average }\end{array}$ & $\begin{array}{c}2 \cdot 3^{*} \\
\text { average }\end{array}$ \\
\hline \multirow[t]{2}{*}{$\begin{array}{l}\text { Ankylosing } \\
\text { Spondylitis }\end{array}$} & $\begin{array}{l}1 \\
2 \\
3 \\
4 \\
5 \\
6\end{array}$ & $\begin{array}{l}\mathbf{M} \\
\mathbf{M} \\
\mathbf{M} \\
\mathbf{M} \\
\mathbf{F} \\
\mathbf{M}\end{array}$ & $\begin{array}{l}42 \\
29 \\
26 \\
27 \\
41 \\
33\end{array}$ & $\begin{array}{r}9 \\
6 \\
12 \\
5 \\
7 \\
10\end{array}$ \\
\hline & $\begin{array}{c}6 \\
\text { total }\end{array}$ & $\begin{array}{ll}5 & \mathrm{M} \\
1 & \mathrm{~F}\end{array}$ & $\begin{array}{c}33 \\
\text { average }\end{array}$ & $\begin{array}{c}8 \cdot 2^{*} \\
\text { average }\end{array}$ \\
\hline
\end{tabular}

* Normal ranges for this laboratory: Male $6-18 \mathrm{mg} . / 24 \mathrm{hrs}$. Female 4-14 mg./24 hrs.

published elsewhere (Pond, 1953a) and summaries of the main findings are presented in Table II.

TABLE II

FRACTIONATION OF 17-KETOSTEROIDS

(mg./24 hrs unless stated)

\begin{tabular}{|c|c|c|c|c|c|c|c|c|c|c|c|c|c|c|c|c|c|c|c|c|}
\hline \multirow{3}{*}{ Category } & \multirow{3}{*}{$\begin{array}{l}\text { Average } \\
\text { Age } \\
\text { (yrs) }\end{array}$} & \multirow{3}{*}{ Sex } & \multicolumn{2}{|c|}{$\begin{array}{c}\text { Total 17- } \\
\text { ketosteroids }\end{array}$} & \multicolumn{4}{|c|}{$\begin{array}{c}\text { Fractions I, II, III } \\
B \text { fraction }\end{array}$} & \multicolumn{4}{|c|}{$\begin{array}{c}\text { Fraction IV } \\
\text { Androsterone }\end{array}$} & \multicolumn{4}{|c|}{$\begin{array}{c}\text { Fraction V } \\
\text { Etiocholanolone }\end{array}$} & \multicolumn{4}{|c|}{$\begin{array}{c}\text { Fractions VI and VII } \\
11 \beta \text { hydroxy } \\
17 \text {-ketosteroids }\end{array}$} \\
\hline & & & \multirow[t]{2}{*}{ Range } & \multirow[t]{2}{*}{$\begin{array}{c}\text { Aver- } \\
\text { age }\end{array}$} & \multicolumn{2}{|c|}{ Range } & \multicolumn{2}{|c|}{ Average } & \multicolumn{2}{|c|}{ Range } & \multicolumn{2}{|c|}{ Average } & \multicolumn{2}{|c|}{ Range } & \multicolumn{2}{|c|}{ Average } & \multicolumn{2}{|c|}{ Range } & \multicolumn{2}{|c|}{ Average } \\
\hline & & & & & No. & $\%$ & No. & $\%$ & No. & $\%$ & No. & $\%$ & No. & $\%$ & No. & $\%$ & No. & $\%$ & No. & $\%$ \\
\hline Normal & 27 & $\mathbf{M}$ & $7-18$ & 12 & $\begin{array}{l}1 \cdot 1- \\
4 \cdot 9\end{array}$ & $14-36$ & $2 \cdot 5$ & 21 & $\begin{array}{l}2 \cdot 4- \\
6 \cdot 3\end{array}$ & $28-48$ & $4 \cdot 3$ & 36 & $\begin{array}{l}1 \cdot 9 \\
6 \cdot 1\end{array}$ & $24-41$ & $3 \cdot 6$ & 30 & $\begin{array}{l}0.8= \\
1.6\end{array}$ & $7-15$ & $1 \cdot 2$ & 10 \\
\hline Normal & 25 & $\mathbf{F}$ & 4-14 & 8 & $\begin{array}{l}0 \cdot 6= \\
2 \cdot 9\end{array}$ & $12-26$ & $1 \cdot 6$ & 20 & $\begin{array}{l}1 \cdot 1- \\
5 \cdot 2\end{array}$ & $24-43$ & $2 \cdot 5$ & 31 & $\begin{array}{l}1 \cdot 2- \\
5 \cdot 3\end{array}$ & $\mid 30-42$ & $2 \cdot 9$ & 35 & $\begin{array}{l}0 \cdot 5- \\
1 \cdot 0\end{array}$ & $5-16$ & $0.7 \mid$ & 9 \\
\hline $\begin{array}{l}\text { Sjögren's } \\
\text { Disease }\end{array}$ & 54 & $\mathbf{F}$ & $1-3$ & $2 \cdot 3$ & $\begin{array}{l}0 \cdot 1- \\
0 \cdot 3\end{array}$ & $8-13$ & $0 \cdot 2$ & 9 & $\begin{array}{l}0 \cdot 3- \\
1 \cdot 0\end{array}$ & $15-31$ & 0.6 & 26 & $\begin{array}{l}0 \cdot 3- \\
1 \cdot 9\end{array}$ & $25-48$ & $1 \cdot 0$ & 44 & $\begin{array}{l}0 \cdot 3- \\
0 \cdot 8\end{array}$ & $19-25$ & $0.5 \mid$ & 21 \\
\hline $\begin{array}{l}\text { Ankylosing } \\
\text { Spondylitis }\end{array}$ & 33 & $\begin{array}{ll}5 & \mathrm{M} \\
1 \mathrm{~F}\end{array}$ & $5-12$ & $8 \cdot 2$ & $\begin{array}{l}0 \cdot 8- \\
4 \cdot 6\end{array}$ & $17-38$ & $2 \cdot 1$ & 27 & $\begin{array}{l}1 \cdot 1- \\
4 \cdot 3\end{array}$ & $20-43$ & $2 \cdot 4$ & 21 & $\begin{array}{l}2 \cdot 0= \\
3 \cdot 9\end{array}$ & $23-44$ & $2 \cdot 7$ & 35 & $\begin{array}{l}0 \cdot 3- \\
0 \cdot 7\end{array}$ & $4-9$ & 0.6 & 8 \\
\hline
\end{tabular}


All the total 17-ketosteroid estimations in patients with Sjögren's syndrome gave results of between 1 and $3 \mathrm{mg}$. $/ 24 \mathrm{hrs}$ (average $2 \cdot 3 \mathrm{mg}$., i.e. below the lower limit of normal for women for this laboratory) (see Table I). In contrast, the results in the patients with ankylosing spondylitis were all within normal limits. None approached the upper limit of the normal range as suggested by the work of Davison and others (1947), but on the contrary, some approached the lower limit of normality.

Fractionation of the 17-ketosteroid extracts showed the following trends in steroid excretion in these two types of patient:

The patients with Sjögren's disease showed a lowering of all fractions and in particular a lowering of the $\beta$ fraction, which is generally considered to be an indication of adrenocortical activity.

The 11-oxy-17-ketosteroid fraction (a probable breakdown product of the adrenal glucocorticoids) was rather low in one patient, but within normal limits in the other two.

One patient showed a relatively raised etiocholanolone excretion, which has been found by other workers to be characteristic of patients with debilitating or malignant disease (Robinson and Goulden, 1949). Etiocholanolone is a non-androgenic isomer of androsterone, and the two fractions normally constitute two-thirds of the total 17-ketosteroids. A rise of this fraction is not necessarily of endocrinological significance.

The fractionation patterns of patients with ankylosing spondylitis were within normal limits with few exceptions: one patient showed an unusually high $\beta$ fraction, for which no apparent explanation could be found; one showed a high value for etiocholanolone, probably suggestive of general debility as previously described; only one showed any significant lowering of the 11-oxy17-ketosteroid fraction, though all were below the mean for normal men.

\section{Discussion}

It is interesting that the excretion of 17-ketosteroids was consistently lowered in all patients with Sjögren's disease. The only other case of Sjögren's disease, in which 17-ketosteroid assay has been recorded in the literature, had a normal value (Frenkel, Hellinga, and Groen, 1951). The low values here may, in part, be due to the advanced ages of these patients, though three of them were under 50 years (36-71 years, average 54$)$. It is also possible that the difficulties of mastication experienced by many of them, may lead to under-nourishment, which will in itself lower 17-ketosteroid excretion. Fractionation studies failed to throw much light on the cause of the low 17-ketosteroid 3 values. The 11-oxy-17-ketosteroids, which are므. probably metabolic end-products of the adrenal? cortical hormone functions, were mainly within $\overrightarrow{\vec{\rho}}$ normal limits. The low $\beta$ fraction suggested $a^{\frac{\rho}{\rho}}$ deficiency in the production of other important? steroids of the adrenal cortex. The significance of the $\frac{\overline{\bar{n}}}{\text {. }}$ excretion of these various steroids is more fully $\vec{\Phi}$ discussed elsewhere (Pond, 1954). The conclusion is that the results of 17 -ketosteroid studies do notes indicate any endocrine abnormality in Sjögren's $\overrightarrow{0}$ disease; they reflect the debilitating nature of the disease, but suggest a potentially normal adreno- $-\bar{\sigma}$ cortical function.

The results of Davison and others (1947) in ankylosing spondylitis cannot be confirmed. Three $\vec{\omega}$ of those cases were complicated by other conditions, anaemia, pulmonary tuberculosis, and muscu- 9 lar dystrophy, which might lower the 17-ketosteroide output, but no explanation can be offered for the consistent failure to find high values. Fractionations of the 17-ketosteroids showed no abnormality of the type of steroid excreted with the exception of one rather high $\beta$ fraction. No explanation can beco offered for this, but it has also been found occa- $\$$ sionally in normal men. One patient showed changesi reflecting the debilitating nature of the disease, as in Sjögren's patients. Again, there is no suggestion that these patients have any endocrine abnormalityo of androgen function, although adrenocorticalo activity as represented by excretion of the $11-\beta-\frac{2}{\Rightarrow}$ hydroxy 17-ketosteroids seems to be slightly below? the average. This may be associated with a low adrenal corticoid excretion, which is interesting since these patients often respond well to cortisone.

\section{Summary}

Patients with Sjögren's disease and ankylosing spondylitis were studied for abnormality of thes 17-ketosteroid excretion, both by total 24-hre urinary assays and by fractionation studies on the urinary extracts. The patients with Sjögren's disease show consistently lowered total urinary 17-keto을. steroid values, possible reasons for which arqu discussed. In other respects little abnormality of 17-ketosteroid excretion was found, and there was no suggestion of any endocrine basis for the disease. N Similarly, little abnormality could be found ino the patients with ankylosing spondylitis in thi§o respect, and the results of previous workers, whow found a raised 17-ketosteroid excretion in many? patients of this type, were not confirmed.

I wish to thank Professor C. H. Gray for facilities for these experiments and for advice and encouragement吕 throughout; the physicians of King's College Hospital, $\stackrel{\mathbb{Q}}{\varrho}$ 
especially Dr. R. S. Bruce Pearson, for their co-operation in the loan of suitable patients; and Miss Jane Cowan for technical assistance.

The work was carried out during the tenure of a William Gibson research scholarship for medical women, and I am also indebted to the governors of King's College Hospital for a grant from the endowment fund.

\section{REFERENCES}

Davison, R. A., Koets, P., and Kuzell, W. C. (1947). J. clin. Endocr., 7, 201.

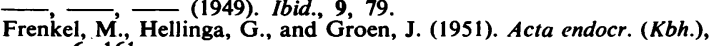
6, 161.

Pond, M. H. (1951), Lancet, 2, 906.

(1953a). Thesis for degree of M.D., University of Cambridge. (1954). J. Endocr. In the press.

Robinson, A. M., and Goulden, F. (1949). Brit. J. Cancer, 3, 62.

Excrétion des 17-cetosteroïdes dans deux formes rares de la maladie rhumatismale

RÉSUMÉ

L'auteur étudia dans la maladie de Sjögren et dans la spondylarthrite ankylosante l'excrétion urinaire totale par 24 heures des 17-cetostéroïdes et en détermina les fractions au moyen de l'analyse chromatographique.
Dans la maladie de Sjögren il trouva constamment le taux diminué, mais ne constata aucune autre anomalie des 17-cetostéroïdes. Il ne pense pas que cela prouve l'origine endocrine de la maladie et il explique la diminution quantitative par des facteurs autres que le processus morbide. L'excrétion des 17-cetostéroïdes était aussi normale dans la spondylarthrite ankylosante, contrairement aux résultats des autres auteurs qui l'avaient trouvé augmentée dans cette maladie.

\section{Excreción de 17-cetoesteroides en dos formas raras de la enfermedad reumática \\ Sumario}

El autor estudió en la enfermedad de Sjögren y en la espondilitis anquilosante la excreción urinaria total por 24 horas de 17-cetosteroides y determinó las fracciones de éstos por medio de analisis cromatográfica. En la enfermedad de Sjögren hubo disminución constante de la tasa, pero ninguna otra anomalía de los 17-cetosteroides. La base endocrina de la enfermedad no se ve, pues, comprobada y el autor sugiere otras causas de la baja excretoria. La excreción de 17-cetosteroides fué también normal en la espondilitis anquilosante, contrariamente a los resultados de otros autores que la hallaron aumentada en esta enfermedad. 